\title{
Modelled effects of ambient UV radiation on a natural Antarctic marine microbial community
}

\author{
M. Nunez ${ }^{1, *}$, A. T. Davidson ${ }^{2}$, K. Michael ${ }^{3}$ \\ ${ }^{1}$ Department of Geography and Environmental Science, University of Tasmania, GPO Box 252-77, Hobart, \\ Tasmania, Australia \\ ${ }^{2}$ Australian Antarctic Division, Department of Environment and Heritage, and Antarctic Climate and \\ Ecosystem Cooperative Research Centre, Channel Highway, Kingston, Tasmania, Australia \\ ${ }^{3}$ Institute of Antarctic and Southern Ocean Studies, University of Tasmania, GPO Box 252-77, Hobart, Tasmania, Australia
}

\begin{abstract}
Ozone depletion over Antarctica has enhanced ultraviolet-B radiation (UVBR, 280 to $320 \mathrm{~nm}$ wavelength). We measured the effect of ambient solar UV radiation on the biomass and species composition of phytoplankton, protozoa, bacteria and dissolved organic carbon (DOC) in natural microbial assemblages from Antarctic coastal waters. Results were modelled to determine the features of the irradiance responsible for changes in the biomass of these microbial components and responses of individual phytoplankton taxa. Model results showed that changes in phytoplankton biomass were primarily due to dose rate, indicating that their UV-induced mortality resulted from the equilibrium between damage and repair. However, there was considerable variability between individual species in their response to dose and dose rate. Changes in protozoan biomass were mainly due to dose and were likely due to community-level, trophodynamic interactions. UV radiation did not measurably affect bacterial biomass, but resulted in increasing concentrations of DOC. We found a threshold of erythemal irradiance of $28 \mathrm{~mW} \mathrm{~m}^{-2}$, approximating peak noon-time irradiance at $3.6 \mathrm{~m}$ depth near the summer solstice in Antarctic coastal waters, below which no change in the community structure was observed, but above which phytoplankton mortality and protozoan biomass increased. Our results indicate that enhanced UVB radiation in Antarctic waters increases phytoplankton mortality and causes changes in the structure, function and composition of the microbial community that are likely to return more photoassimilated carbon to the atmosphere.
\end{abstract}

KEY WORDS: Antarctic $\cdot$ Model $\cdot \mathrm{UV} \cdot$ Ozone $\cdot$ Marine microbes

\section{INTRODUCTION}

Stratospheric ozone concentrations over Antarctica commonly fall below $50 \%$ and can decline to as little as $26 \%$ of pre-ozone hole values during austral spring, with some depletion persisting over summer (Frederick \& Lubin 1994, Weiler \& Penhale 1994). Due to depletion of stratospheric ozone, Antarctic erythemal ultraviolet (UV) irradiances have increased approximately $130 \%$ during spring and 50 to $100 \%$ around the summer solstice (Frederick \& Lubin 1994, Jones \& Shanklin 1995, Madronich et al. 1998, Kerr 1998). Thus, ultraviolet-B radiation (UVBR) is enhanced throughout the period of greatest biological production in Antarctic waters, thereby increasing the ratio of UVB (280 to $320 \mathrm{~nm}$ ) to both UVA (320 to $400 \mathrm{~nm}$ ) and PAR (photosynthetically active radiation, 400 to $750 \mathrm{~nm}$ ) (Jones \& Shanklin 1995, Madronich 1995).

The evidence that UVBR can damage phytoplankton is overwhelming (e.g. UNEP 1991). Maximal depletion of ozone coincides with the proliferation of plankton in the sea ice and marginal ice zone (MIZ) (Vincent \& Roy 1993, Marchant 1997, Davidson 1998), and organisms inhabiting these environments are likely to experience enhanced exposures to UVBR (Davidson 1998). Its effect on phytoplankton alone was considered to be 
pervasive, with molecular and cellular impacts on autotrophs flowing, via the food web, to cause changes on the ecosystem level (Vincent \& Roy 1993). Most research on the effect of UV on marine microbes has focussed on its impact on phytoplankton (Davidson 1998). However, Bothwell et al. (1994) first showed that studies of UV-induced effects on single species or trophic levels could not be used to predict the impacts in natural communities, as they did not incorporate the effect of UV on trophic interactions. Recent studies show that UVB also directly impacts the production, growth, survival and species composition of bacteria, viruses and protozoa (Jeffrey et al. 2000, Mostajir et al. 2000, Vernet 2000), increasing the likelihood that ecosystem-level changes will result from Antarctic ozone depletion. However, few studies have addressed UV-induced changes in the dynamics of natural marine microbial assemblages (Keller et al. 1997a,b, Wickham \& Carstens 1998, Mostajir et al. 1999) and findings vary greatly. To our knowledge, no studies have been conducted in Antarctic marine waters other than those we have performed (Davidson \& van der Heijden 2000, Davidson \& Belbin 2002).

Models can be used to better understand and predict UV irradiance and its effect on marine microbes (e.g. Neale et al. 1998b). However, the absence of studies that simultaneously determine the effect of UV exposure on entire Antarctic marine microbial communities has hampered development of such community-based models. In earlier experiments we measured the effect of UV irradiance and exposure duration on an Antarctic marine microbial community (phytoplankton, protozoa and bacteria) (Davidson \& van der Heijden 2000, Davidson \& Belbin 2002). Based on these measurements, we have modelled UV-induced changes in the structure and function of an Antarctic marine microbial community, determined whether dose or dose rate elicits these changes and used the model to predict the effect of UV-induced changes in microbial communities in Antarctic coastal waters.

\section{MATERIALS AND METHODS}

The influence of ambient UV radiation on bacteria, phytoplankton and protozoa was determined over a range of light environments to simulate increasing depth in the water column. For detailed methods of sample acquisition, preparation and incubation see Davidson \& van der Heijden (2000) and Davidson \& Belbin (2002).

Light measurement. Light measurements were made using an SR9910 Macam double-grating spectroradiometer. Wavelengths between 280 and $400 \mathrm{~nm}$ were scanned at $1 \mathrm{~nm}$ wave steps every $5 \mathrm{~min}$ during the in vivo exposure of protist assemblages to solar radiation. The downwelling irradiance at each wavelength was multiplied by the percent transmittance of WhirlPak bags and UV-attenuating screens (see below). The spectral irradiance of each light treatment was then erythemally weighted and secondary inter-comparison was performed between the erythemal downwelling irradiance obtained from the spectroradiometer and coincident measurements of erythemal UV collected using a 501B solar light UVbiometer by the Australian Radiation Protection and Nuclear Safety Agency. Erythemal radiance was used due to its similarity to plant and DNA action spectra, ease of cross-calibration with biometer data and the fact that the experiments examined interactive responses of an entire plankton community for which more specific physiological weighting functions were not applicable.

Sampling. Studies were conducted at Davis Station $\left(68^{\circ} 35^{\prime} \mathrm{S}, 77^{\circ} 58^{\prime} \mathrm{E}\right)$, East Antarctica. Seawater containing a natural plankton assemblage was pumped from $10 \mathrm{~m}$ depth, $2 \mathrm{~km}$ offshore on 7 January 1998. The seawater was returned to the laboratory under subdued light, and was filtered through $200 \mu \mathrm{m}$ mesh into a sterile, acid-cleaned, polythene-lined $200 \mathrm{l}$ stainless steel drum to remove metazoan grazers. Three replicate subsamples of $1 \mathrm{l}$ and $20 \mathrm{ml}$ were obtained to determine the initial $\left(T_{0}\right)$ concentrations of protists and bacteria, respectively. A further 132 sterile, UV-transmissive, $500 \mathrm{ml}$ Nasco WhirlPak natural polythene bags were filled with approximately $350 \mathrm{ml}$ aliquots of natural plankton assemblage. WhirlPaks were exposed to ambient solar UV radiation in outdoor incubation tanks. Thirty bags were placed beneath various thicknesses of borosilicate glass that attenuated UV to equivalent water column depths (ED) of 1.0, 2.0, 3.0 and $3.6 \mathrm{~m}$. A further 12 bags were held beneath UV-stabilised polycarbonate and comprised the control treatment at ED $\geq 20 \mathrm{~m}$. At the end of each irradiance period $(0,8 \mathrm{~h} ; 1,2$, 4 and 7 d), 3 replicate WhirlPak bags were thoroughly mixed and aliquots of $50 \pm 5 \mathrm{ml}$ from each bag were poured into a sterile polycarbonate jar. The WhirlPak bags were then resealed and, together with a further 3 replicate bags from each light treatment, transferred to the control irradiance treatment and allowed to grow in the absence of short wavelength UV (post-UV incubation). The total duration of UV irradiation plus post-UV incubation was $10 \mathrm{~d}$ for all bags.

Following post-UV incubation, the 6 replicate WhirlPaks for each light treatment and each irradiance time were randomly paired and the pairs were pooled. Approximately $50 \pm 5 \mathrm{ml}$ was again transferred to sterile polycarbonate jars, and the total bacterial concentration, determined by microscopy (as below). A known volume (approximately half) of the sample was 
transferred to a glass $1 \mathrm{l}$ bottle, fixed with $1 \mathrm{ml}$ of acid Lugol's iodine and allowed to sediment for $\geq 48 \mathrm{~h}$. The supernatant was removed by aspiration, and the concentrated sample $(\sim 20 \mathrm{ml})$, stored at $4^{\circ} \mathrm{C}$ prior to the determination of protist concentration.

Bacterioplankton. Total bacterioplankton concentration was obtained from samples stained with 4',6 diamidino-2-phenolindole (DAPI) (Sigma). A known sample volume was filter-concentrated to approximately $2 \mathrm{ml}$ in a $25 \mathrm{~mm}$ diameter filtration apparatus fitted with $0.2 \mu \mathrm{m}$ pore size black polycarbonate membrane filters (Poretics), and $60 \mu \mathrm{l}$ of $500 \mu \mathrm{g} \mathrm{ml}^{-1}$ solution of DAPI in MilliQ water was added. The samples were mixed, held in the dark for 15 min, filtered to dryness and mounted on slides, and bacteria were counted over 10 replicate fields using UV epifluorescence on a Zeiss Axiovert at $1000 \times$ magnification. To calculate bacterial carbon, we used the mean cell volume for near-shore bacteria at Davis Station, Antarctica, of $0.13 \mu^{3}$ (Archer et al. 1996) and a carbon conversion

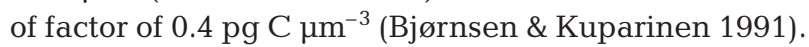

Protists. Aliquots of the concentrated samples (see above) were sedimented in Utermöhl cylinders, and observed using Nomarski optics on a Zeiss Axiovert inverted microscope at 400 or $1000 \times$ magnification. Cell counts were performed over 5 randomly chosen fields for each of the 3 independent replicate samples at each exposure time and light treatment. Heterotrophic protists were identified under transmitted light by the absence of chlorophyll, chloroplasts and starch. The mean and standard error of cell concentrations were then calculated for identified species or groups of plankton.

To aid identification of protist species, samples of concentrate were also pipetted onto formvar-coated copper grids, fixed for $60 \mathrm{~s}$ with $2 \% \mathrm{OsO}_{4}$ vapour, rinsed gently with distilled water, air-dried and then shadow-cast with chromium metal vapour. Shadowcast preparations were subsequently examined using a Phillips CM 100 transmission electron microscope.

To calculate microbial carbon biomass, 50 to 100 cells of each taxon were measured using an ocular micrometer at 400 or $1000 \times$ magnification. The cell volumes were multiplied by 1.33 to compensate for cell shrinkage as a result of Lugol's fixation (Dehairs et al. 1992); the cell carbon was calculated using the conversion statistics: $0.19 \mathrm{pg} \mathrm{C} \mathrm{mm}^{-3}$ for ciliates (Putt \& Stoeker 1989), $0.183 \mathrm{pg} \mathrm{C} \mathrm{mm}^{-3}$ for heterotrophic

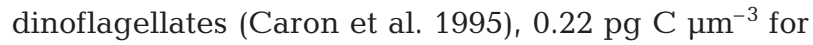
heterotrophic nanoflagellates (Børsheim \& Bratak 1987) and pg $\mathrm{C}=0.109 \times(\text { live cell volume })^{0.991}$ for all other autotrophic and heterotrophic cells (Montagnes et al. 1994). To minimise the number of variables (microbe species), the cell carbon concentrations attributable to each functional component of the microbial community (phytoplankton, protozoa and bacteria) were calculated, and the concentrations for each 10-min-integrated duration of exposure to UV were then determined (see below).

Modelling. The modelling comprised 3 facets. Firstly, a model of carbon flux was developed between the microbial components and dissolved organic carbon (DOC) pool in the absence of UV stress. The model develops empirical carbon transfer constants that are based on measured concentrations in the absence of UV stress. These results were then used in the second model facet in which UV stress was added. A second set of empirical constants are developed based on root mean square (RMS) minimisation of the difference between measured and modelled carbon concentrations. The complete model was then used to examine the impact of changes in UV dose, dose rate and sensitivity to UV exposure on the biomass of Antarctic marine microbes and trophodynamics of the resultant communities. A third modelling facet was then developed to study individual variability in the response of phytoplankton species to UV radiation.

Microbial model without UV stress. A carbon flux model was generated to describe the flow of carbon between each component of the microbial community in the absence of UV stress. The model (modified after Moloney \& Field 1991, Lancelot et al. 1997) assumed that nutrient availability does not limit phytoplankton growth in Antarctic coastal waters. Changes in carbon content of phytoplankton $(P h)$, protozoa $(Z)$ and bacteria $(B)$, along with dissolved organic matter $(D)$, were derived, the 4 equations being:

$\Delta P h=\operatorname{Production}-\operatorname{grazing}(P h)-\operatorname{respiration}(P h)$
$\Delta Z=\operatorname{Grazing}(P h)+\operatorname{grazing}(B)-\operatorname{respiration}(Z)$
$\Delta B=\operatorname{Uptake}(D)-\operatorname{grazing}(B)-\operatorname{respiration}(B)$
$\Delta D=\operatorname{Respiration}(B)+\operatorname{respiration}(Z)-\operatorname{uptake}(D)$

where delta refers to a 10 min change in carbon concentrations $\left(\mu \mathrm{g} \mathrm{l}^{-1}\right)$.

The production term in Eq. (1) was calculated using the relationship presented in Lancelot et al. (1997):

$$
\text { phot }=\left[K_{\max }\left(1-\exp \left(\alpha I / K_{\max }\right)\right]\right.
$$

where $K_{\max }$ equals the 10 -min-integrated maximum photosynthesis capacity $(0.01), \alpha$ is the photosynthetic efficiency $\left(1.805 \times 10^{-7}\left[\mu \mathrm{E} \mathrm{m} \mathrm{m}^{-2}\right]^{-1}\right)$ and $I$ is the photosynthetically active irradiance $\left(\mu \mathrm{E} \mathrm{m}^{-2}\right)$. As we did not measure the photosynthetic irradiance, I was estimated using field measurements of UV erythemal irradiance and adjusted to PAR using linear regressions based on concurrent PAR, broadband and erythemal solar irradiance under clear-sky conditions collected in Hobart, Australia. The coefficient of variance between erythemal UV and PAR is 0.87, which includes any daily variability in total ozone column. As there was no marked ozone depletion during the experiment, use of 
data in Hobart to predict PAR from erythemal irradiance at Davis Station was justifiable.

The production term in Eq. (1) is equal to photosynthesis (Eq. 5) minus lost carbon due to photo-inhibition by photosynthetically active radiation (PAR) and respiration. Given that these 2 last terms are difficult to quantify, it was decided to work with a 'net production' term equal to photosynthesis times an empirically adjusted constant, $a_{1}$, which accounts for losses due to photo-inhibition and respiration.

Protozoan grazing of phytoplankton (in Eqs. 1 \& 2) and bacteria (in Eqs. 2 \& 3) are calculated using the relationship and constants developed by Lancelot et al. (1997), which are based on Michaelis-Menten kinetics:

$$
\operatorname{grazing}(I)=C_{\max } \frac{I}{I+C_{i}} Z
$$

where $Z$ is the protozoan carbon concentration, $I$ is the carbon concentration due to grazing of either phytoplankton or bacteria, $C_{\max \text { i }}$ is the maximum protozoan ingestion rate of phytoplankton $(0.00310 / 10 \mathrm{~min})$ or bacteria $(0.00408 / 10 \mathrm{~min})$ and $C_{i}$ is a constant that takes the value 3.4 or 2.6 for grazing of phytoplankton or bacteria, respectively (Lancelot et al. 1997).

Similarly, the uptake of DOC $(D)$ by bacteria is also given by a Michaelis-Menten kinetic, adjusted by a constant $a_{2}$ to account for respirational losses:

$$
\operatorname{uptake}(D)=a_{2} \frac{D}{D+10} B
$$

Finally, protozoan respiration in Eq. (2) was calculated as the product of protozoan concentration multiplied by an empirical constant $a_{3}$, which was adjusted subject to error minimisation.

Solutions of Eqs. (1) to (4) revolved around the 3 empirical constants, $a_{1}$ to $a_{3}$, with the remaining terms being explicitly defined as discussed above. The procedure followed was to run Eqs. (1) to (4) subject to the initial and final conditions for phytoplankton, bacteria and protozoa given in Table 1. Final conditions corresponded to concentrations after $10 \mathrm{~d}$ of exposure to no UV light, but similar PAR as received by the rest of the samples. The coefficients $a_{1}, a_{2}$ and $a_{3}$ exhibited little covariance and changed linearly with time.

Table 1. Biomass of microbial components at the start and end of the experiment

\begin{tabular}{|lcrl|}
\hline & $\begin{array}{c}\text { Start }(0 \mathrm{~d}) \\
\left(\mu \mathrm{g}^{-1}\right)\end{array}$ & $\begin{array}{c}\text { End }(10 \mathrm{~d}) \\
\left(\mu \mathrm{g} \mathrm{l}^{-1}\right)\end{array}$ & $\begin{array}{c}\text { Adjusted } \\
\text { coefficients }\left(a_{1}\right)\end{array}$ \\
\hline Phytoplankton & 411.8 & 447.0 & $\mathrm{a}_{1}=0.0115$ \\
Bacteria & 57.2 & 66.4 & $a_{2}=0.000549$ \\
Protozoa & 11.7 & 4.3 & $a_{3}=0.00282$ \\
\hline
\end{tabular}

Microbial model with UV stress. The inhibitory effects of UV irradiance on phytoplankton (fuvp), protozoa (fuvz) and bacteria (fuvb) were added to the model. The terms 1 -fuvp, 1 -fuvb and 1 -fuvz (Eqs. 11 to 14) act to reduce the biomass of phytoplankton, bacteria and protozoa, respectively, due to UVinduced mortality. In the most general case the effect of both dose rate and dose may be written as transmission functions of the $10 \mathrm{~min}$ dose rate $\left(\mathrm{mW} \mathrm{m}^{-2}\right)$ or total dose $(J)$ since the start of the experiment:

$$
\begin{aligned}
& \text { fuvp }=\exp \left(-C_{1 \mathrm{DR}} U V-C_{1 \mathrm{D}} S\right) \\
& \text { fuvb }=\exp \left(-C_{2 \mathrm{DR}} U V-C_{2 \mathrm{D}} S\right) \\
& \text { fuvz }=\exp \left(-C_{3 \mathrm{DR}} U V-C_{3 \mathrm{D}} S\right)
\end{aligned}
$$

where $U V$ is dose rate, $S$ is dose and $c_{i \mathrm{DR}}$ and $C_{i \mathrm{D}}$ are empirical constants determining the sensitivity of organism $i$ to either dose rate or dose, respectively. In the modelling process, we also allow for a threshold irradiance value, $U V_{\mathrm{T}}$, below which there is no UVinduced impact, thereby reducing Eqs. (8) to (10) to fuvp $=$ fuvb $=$ fuvz $=1.0$.

Eq. (1) becomes:

$$
\begin{aligned}
\Delta P h= & a_{1} K_{\max }\left[1-\exp \left(\alpha I / K_{\max }\right)\right] \text { fuvp } \\
& -C_{\max } P \frac{P h}{P h+3.4} Z-(1-\text { fuvp }) P h
\end{aligned}
$$

UV-induced mortality of protozoa (fuvz) can reduce protozoan standing stock. The term $C_{\mathrm{P}}$ partitions the carbon from phytoplankton mortality between protozoan uptake and release as DOC. Protozoa gain a yet to be determined fraction $\left[C_{\mathrm{P}}(1-\mathrm{fuvp}) \mathrm{Ph}\right]$ of the decline in phytoplankton biomass by grazing. The other remaining fraction $\left[\left(1-C_{\mathrm{P}}\right)(1-\right.$ fuvp $\left.) P h\right]$ goes to replenish the organic carbon pool. Eq. (2) becomes:

$$
\begin{aligned}
\Delta Z= & C_{\max } P \frac{P h}{P h+3.4} Z+C_{\max B} \frac{B}{B+2.6} Z-a_{3} Z \\
& -(1-\text { fuvz }) Z+C_{\mathrm{P}}(1-\text { fuvp }) P h
\end{aligned}
$$

UV-induced mortality of bacteria (fuvb) can also reduce their standing stock. Eq. (3) becomes:

$$
\Delta B=a_{2} \frac{D}{D+10} B-C_{\max B} \frac{B}{B+2.6} Z-(1-\text { fuvb }) B
$$

Finally, concentrations of DOC may increase due to UV-induced mortality of phytoplankton, protozoa and bacteria and to respiration by protozoa and bacteria. These gains are offset by direct losses from bacteria uptake:

$$
\begin{aligned}
\Delta D= & -a_{2} \frac{D}{D+10} B+a_{3} Z+\left(1-C_{\mathrm{P}}\right)(1-\text { fuvp }) P h \\
& +(1-\text { fuvb }) B+(1-\text { fuvz }) Z
\end{aligned}
$$

Eqs. (11) to (14) contain 8 unknown terms, $C_{1 \mathrm{D}}, C_{2 \mathrm{D}}$, $C_{3 \mathrm{D}}, C_{1 \mathrm{DR}}, C_{2 \mathrm{DR}}, C_{3 \mathrm{DR}}, U V_{\mathrm{T}}$ and $C_{\mathrm{P}}$. Microbial data was obtained at intervals of $0.333,1,2,4$ and $7 \mathrm{~d}$ of expo- 
sure. However, changes in the microbial community potentially occurred at much shorter time scales. We iterated each of the unknown constants using random numbers (RN) constrained between 0 and 1 . The value was accepted if it lowered the RMS error (see Eq. 15) of the predicted microbial data. We then examined the next constant, and the procedure was repeated until all 5 constants were sampled. The entire procedure was then repeated until increases in all components $(\Delta P h$, $\Delta Z, \Delta B, \Delta D$ ) were negligible. This was usually reached at 2000 iterations. Trial and error indicated that convergence was a strong function of the maximum value the $\mathrm{RN}$ was allowed to change between iterations. Therefore, each RN generated, varying between 0 and 1, was multiplied by a decimal value that limited the maximum RN generated.

Fig. 1 shows the procedure structured as a FORTRAN program. The initial RMS was set to a high value, therefore easing the entry into the randomly generated constants. Stable values were quickly reached after 100 iterations, although minor adjustments may occur up to 2000 iterations.

The RMS value was an average of the 3 RMS values for the phytoplankton, protozoa and bacteria, expressed as a percentage of their initial value, namely:

$R M S=\frac{1}{3}\left[\frac{R M S\left(P h i-P h i^{\prime}\right)}{P h_{0}}+\frac{R M S\left(Z i-Z i^{\prime}\right)}{Z_{0}}+\frac{R M S\left(B i-B i^{\prime}\right)}{B_{0}}\right]$

where the primes denote model values, unprimed are measured data and the 0 subscripts refer to initial measured values. The RMS summation is performed over 20 data points for each of the 3 microbial communities (5 different times and 4 different depths). Division by initial quantities ensured that all 3 communities were represented equally in the RMS function.

Some smoothing of the data was also deemed necessary to improve model convergence. Measured carbon concentrations were smoothed by applying a multiple linear regression of depth and time to measured concentrations of phytoplankton, protozoa and bacteria. This procedure ensured that the basic trends in the variables remained, while minimising measurement errors.

Individual responses. The previous sections examined the ecosystem response to UVR using bulk carbon concentrations for phytoplankton, protozoa and bacteria. Results obtained refer to integrated system responses, but are not applicable to individual species in the system as they vary widely in size, concentration and sensitivity to UV exposure.

In principle, it was technically possible to apply a Monte Carlo approach to the species components in a manner similar to the previous section. However, the number of unknown coefficients and interrelationships

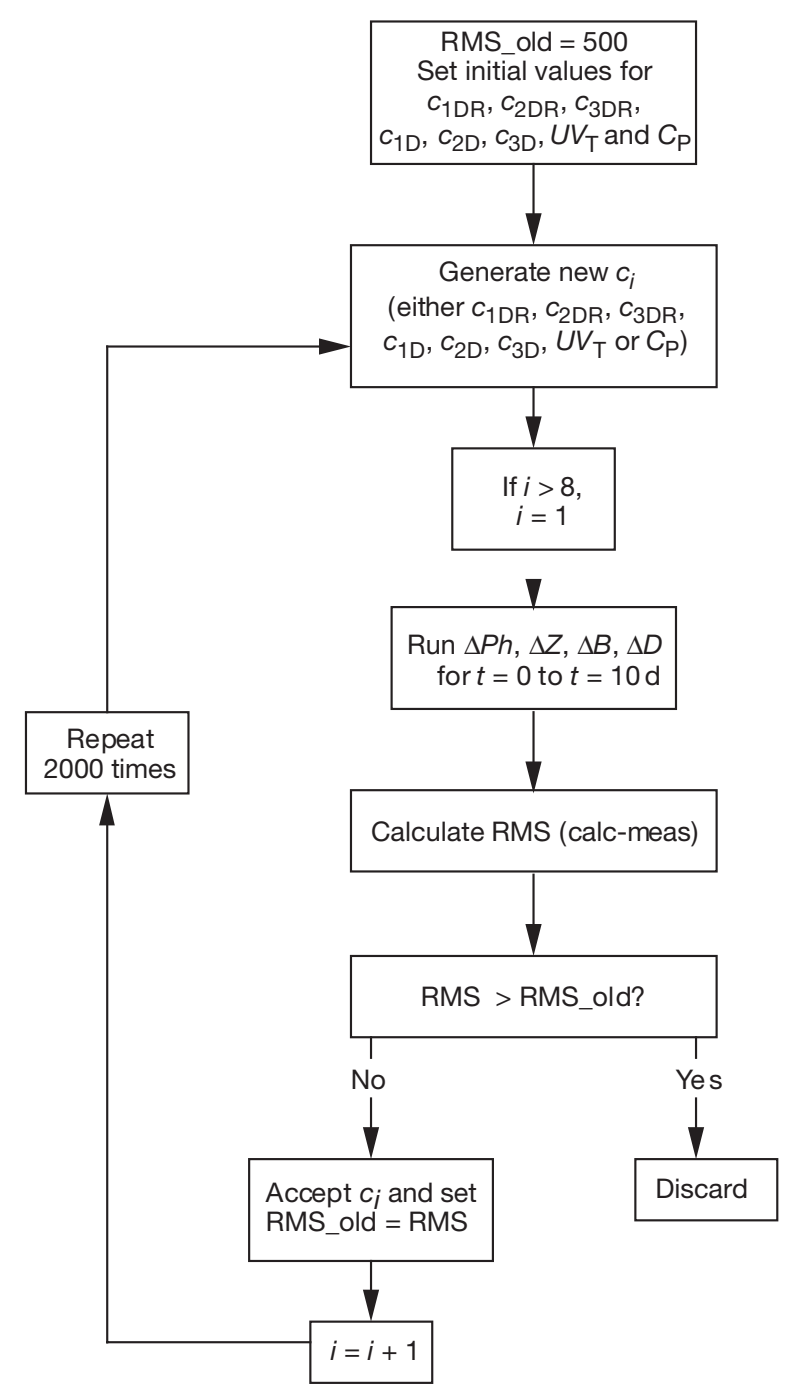

Fig. 1. Flow diagram illustrating the structure of the FORTRAN program used to calculate the various coefficients determining UV stress

between the various components made this approach untenable. Thus, we used a multiple linear regression approach that allowed us to examine the taxon-specific responses, while maintaining a strong emphasis on the physical processes involved.

We did not examine individual responses of components of the bacterial or protozoan community. No taxonomic separation of the bacterial community was performed in this study; bacterial concentrations proved relatively insensitive to UV exposure, or UVB-induced changes were poorly resolved in our experiments. Concentrations of all protozoan taxa were enhanced by exposure to UV, though the timing and magnitude of responses differed slightly between taxa (Davidson \& Belbin 2002). In contrast, phytoplankton dominated total microbial carbon concentrations and showed 
strongly species-specific responses to UV exposure. Thus, we exclusively examined the taxon-specific responses of phytoplankton to UVR. Multiple linear regressions treated radiation and photosynthesis as the sole determinants of species concentration at the expense of scavenging. Though this was a simplification of the factors determining phytoplankton species composition and disregarded protozoan grazing, the magnitude of the carbon changes incurred by the protozoa (Eq. 6) suggests that errors introduced by this assumption were not large.

Nine phytoplankton taxa were monitored over time (after Davidson \& Belbin 2002), and relationships between the biomass of each species and a range of radiation variables were examined. In a multiple regression format, it may be expressed as:

$P_{i}=\beta_{0 i}+\beta_{1 i}$ photosynthesis $+\beta_{2 i}$ dose $+\beta_{3 i}$ dose rate

where $P_{i}$ is the phytoplankton concentration for species $i$ at any time $t_{i} \beta_{0 i}, \beta_{1 i}, \beta_{2 i}$ and $\beta_{3 i}$ are regression constants defined for species $i_{\text {; }}$ and photosynthesis, dose and dose rate are radiation-related quantities also estimated at time $t$. Thus, they define the relative effect of photosynthesis, dose and dose rate on speciesspecific phytoplankton carbon. A non-significant coefficient implies that the radiation quantity (either photosynthesis, dose, or dose rate) is not acting for a particular species $i$. A significant and positive or negative coefficient implies that each radiation quantity is causing the biomass of a particular phytoplankton taxon to increase or decrease, respectively. The $\beta_{0 i}$ term is the regression constant, and is not relevant to the discussion.

Using the radiation model described in the previous section, photosynthesis and erythemal UVR are calculated for every $10 \mathrm{~min}$ for the 1, 2, 3 and $3.6 \mathrm{~m}$ depth and integrated at every $10 \mathrm{~min}$ time step. The integration could take any form (exponential, linear, etc.), and may have any threshold above which it affects species-specific phytoplankton biomass. At selected times, the 3 integrated radiation quantities were compared with measured phytoplankton carbon for species $i$. Note that it must also be integrated in time to be related to the phytoplankton species $i$ at time $t$. Thus, for any species $i$ there are 20 carbon concentration measurements ( 5 time periods $\times 4$ depths) and 20 estimates of photosynthesis, dose and dose rate. These form the basis of the multiple linear regressions. The radiation quantities are explicitly given below as time integrals, which can then be related to the phytoplankton $i$ at time $t$ :

$$
\text { photosynthesis }=\sum_{T_{0}}^{t} K_{\max }\left(1-\exp \left(\frac{\alpha I_{t}}{K_{\max }}\right) \Delta t\right.
$$

$$
\begin{gathered}
\text { dose }=\sum_{T_{0}}^{t} U V_{t} \Delta t \\
\text { dose rate }=\sum_{T_{0}}^{t} f_{1}\left(U V_{t}\right) \Delta t
\end{gathered}
$$

where $f_{1}\left(U V_{t}\right)$ is a response function defining how UV dose rate is modified in response to a biological impact on species $i$. Several functional forms of $f_{1}\left(U V_{t}\right)$ for dose rate (Eq. 19) were examined, including an exponential and linearly increasing dose rate with UVR. Best results were obtained when the response function was constant above a certain threshold, implying that damage exceeded repair. Note that a constant response function is in approximate agreement to the very low UV stress coefficient $c_{1 \mathrm{DR}}$ that was assigned to the bulk phytoplankton species (Eq. 8; see Table 3). The actual value is arbitrary, as the regression will assign optimum coefficients to that given value. The mathematical expression for the function $f_{1}$ is given below:

$$
\begin{aligned}
f_{1} & =0 \text { when } U V_{t} \leq U V_{\mathrm{T}} \\
& =1 \text { when } U V_{t}>U V_{\mathrm{T}}
\end{aligned}
$$

where $U V_{\mathrm{T}}$ is a yet to be determined radiation threshold, and $U V_{t}$ is the radiation at any time $t$. Determining $U V_{\mathrm{T}}$ forms the central part of the analysis, and is illustrated in Fig. 2.

In the analysis, the threshold $U V_{\mathrm{T}}$ can take any value between 0 and an arbitrarily high value of $80 \mathrm{~mW} \mathrm{~m}^{-2}$, which exceeds all the radiation below $1 \mathrm{~m}$ and most dose rates at depths $<1 \mathrm{~m}$. In the analysis shown in Fig. 2, $U V_{\mathrm{T}}$ is given as the product of a constant $K$ times 80 , with $K$ varying between 0 and 0.9 in steps of 0.1 . At each step the regression defined by Eq. (16) is obtained, and after 10 iterations an optimum $K$ (and therefore an optimum $U V_{\mathrm{T}}$ ) is chosen that gives the highest regression.

\section{RESULTS}

\section{Microbial model without UV stress}

The model was run in the absence of UV stress. It involved calculation of 10 min concentrations of phytoplankton, protozoa, bacteria and DOC subject to measured initial and final conditions (Table 1). The constants $a_{1}, a_{2}$ and $a_{3}$ were adjusted to give the correct concentrations at the end of the $10 \mathrm{~d}$ period. Values of $0.015,0.000549$ and 0.0028 were obtained for $a_{1}, a_{2}$ and $a_{3}$, respectively. These values were used in all subsequent modelling involving UV stress.

DOC was not measured, and an initial value of $1 \mu \mathrm{g}$ $\mathrm{l}^{-1}$ was used for the model run. This figure was arbi- 


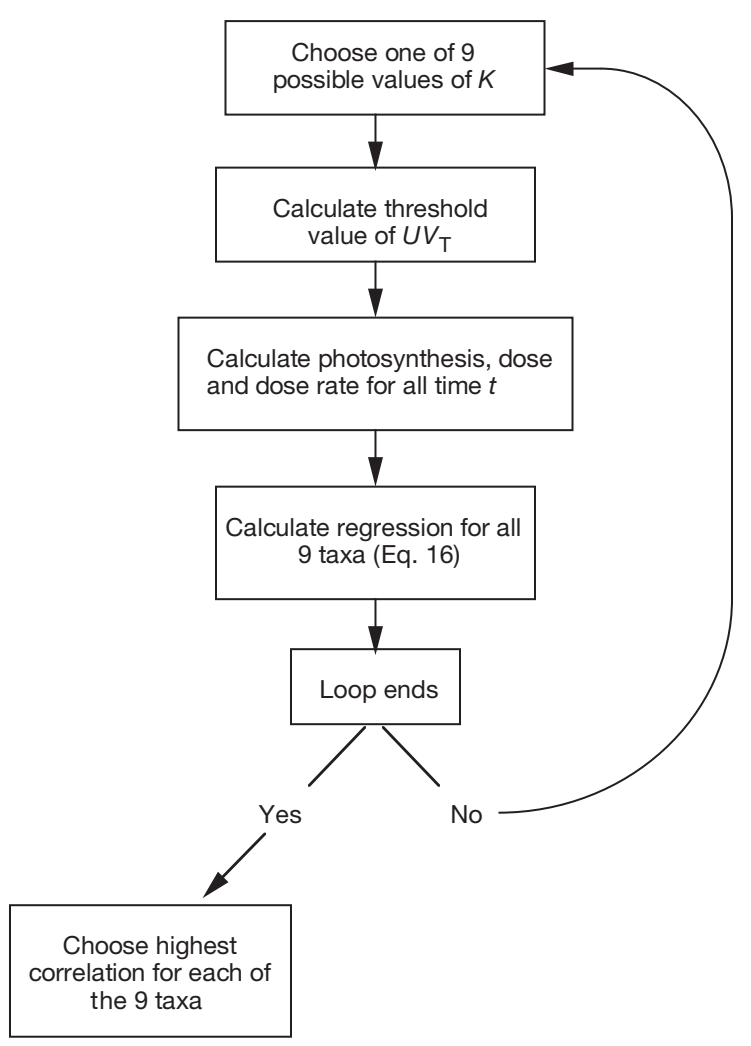

Fig. 2. Procedure followed in determining highest correlation for each phytoplankton species

trary, but based on measured concentrations in Antarctic coastal seawater (Davidson \& Marchant 1992). DOC increased with time in all model simulations and did not limit bacterial production.

\section{Microbial model with UV stress}

Examination of the correlation between the measured data and the model fit (as a function of depth and time) showed the considerable extent to which depth and duration of exposure explained changes in the microbial components. Highest correlation between the model and the data was obtained for the phytoplankton community, for which $78 \%$ of the variance could be explained (Table 2). A lower $\mathrm{R}^{2}$ of 0.24 was obtained for the protozoan community, due to 1 data point that departed from the regression line by approximately 3 standard errors. Calculated concentrations of protozoan cell carbon were strongly affected by the occurrence of large rare species in cell counts. The high departure at the peak in protozoan concentrations was likely due to high measurement errors. A relatively high coefficient of variance was obtained for bacteria, with a probability of $<0.01$ that the relationship occurred by chance.

\section{Effect of dose rate}

Eqs. (8) to (14) were solved subject to initial conditions and as measured at intervals of $0.33,1,2,4$ and 7 d. Dose rate was first examined in isolation; to achieve this we have taken $c_{1 \mathrm{D}}=C_{2 \mathrm{D}}=C_{3 \mathrm{D}}=0$ in Eqs. (8) to (10). The random numbers constraining $c_{1 \mathrm{DR}}, c_{2 \mathrm{DR}}$ and $C_{3 \mathrm{DR}}$ (i.e. $\mathrm{RN} \times C_{i \mathrm{DR}}$ ) were systematically varied between 0 and $10^{-5}$ or 0 and $1.75 \times 10^{-3}$. Having established the maximum span in RN, the algorithm (Fig. 1) was followed to obtain the minimum RMS and the optimum values of $C_{1 \mathrm{DR}}, C_{2 \mathrm{DR}}, C_{3 \mathrm{DR}}, U V_{\mathrm{T}}$ and $C_{\mathrm{P}}$. As mentioned earlier, this procedure was necessary as the character of the convergence is also dependent on the interval in RN.

The plot of the RN interval against the RMS difference showed that the lowest RMS of 0.202 was obtained corresponding to an $\mathrm{RN}$ range equal to 0.0035 (Fig. 3). However, there was a distinct range in $c_{1 \mathrm{DR}}$ from 0.0002 to 0.0005 , in which RMS values were smallest.

\section{Effect of dose}

The procedure followed here was the same as for dose rate except that now $c_{1 \mathrm{DR}}, c_{2 \mathrm{DR}}$ and $c_{3 \mathrm{DR}}$ in Eqs. (8) to (10) were set to 0 and $c_{1 \mathrm{D}}, c_{2 \mathrm{D}}$ and $c_{3 \mathrm{D}}$ were allowed to vary randomly, but were capped to a maximum range. This range varied from a minimum of $10^{-6}$ (RN varying from 0 to $10^{-6}$ ) to $10^{-4}$ (RN varying from 0 to $10^{-4}$ ). The algorithm shown in Fig. 1 was then followed with $C_{i \mathrm{DR}}$ being replaced by $C_{i \mathrm{D}}$. Minimum RMS differences at 0.23 were higher than for dose rate and occurred at a lower RMS range (Fig. 3), but indicated that dose as well as dose rate could lower the RMS error.

Table 2. Multiple linear regression coefficients of the modelled responses versus measured data for phytoplankton, protozoa and bacteria as a function of equivalent depth $h(\mathrm{~m})$ and exposure time $t(\mathrm{~d})$

\begin{tabular}{|lccr|}
\hline & Phytoplankton & Protozoa & Bacteria \\
\hline Int & 365.926 & 8.818 & 126.633 \\
$t$ & -126.864 & 3.117 & -13.415 \\
$h$ & 13.427 & 3.423 & -59.177 \\
$t^{2}$ & 15.618 & -0.652 & 0.115 \\
$h^{2}$ & -12.609 & -1.097 & 14.011 \\
$h t^{2}$ & -2.106 & 0.0972 & 2.229 \\
$h^{2} t$ & 14.783 & -0.411 & -0.024 \\
$h^{2} t^{2}$ & -1.143 & 0.045 & -0.522 \\
$\mathrm{R}^{2}$ & 0.78 & 0.24 & 0.318 \\
$\mathrm{p}$ & $<0.001$ & $<0.05$ & $<0.01$ \\
\hline
\end{tabular}




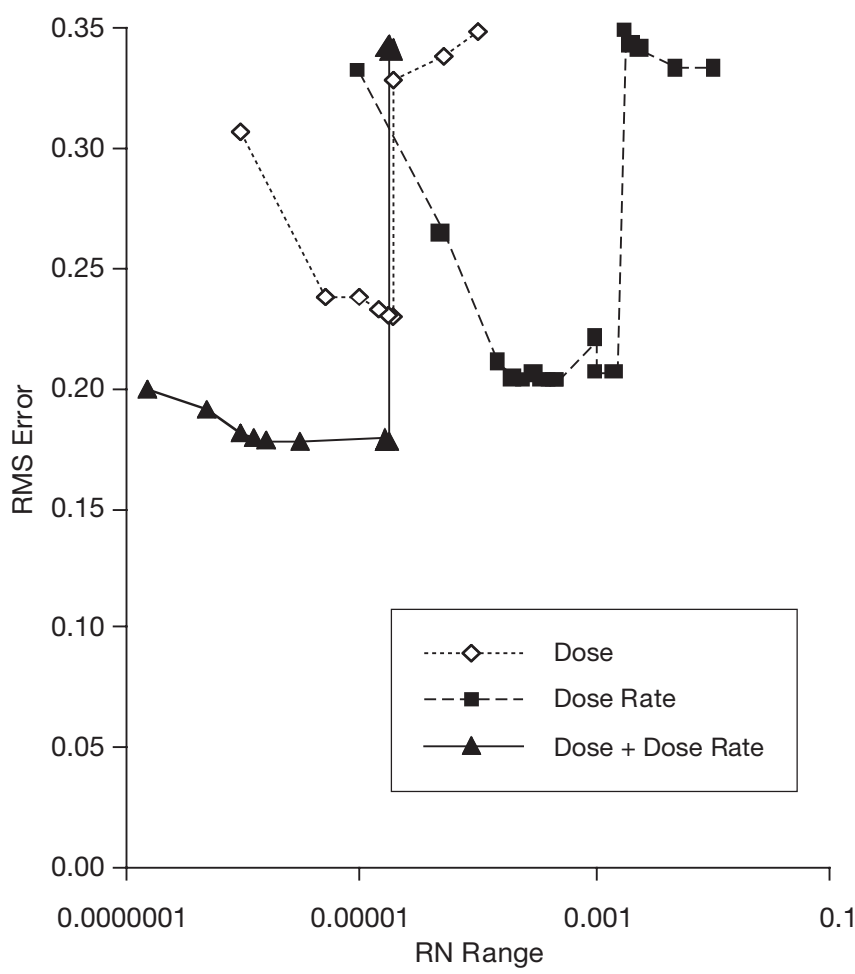

Fig. 3. Model root mean square (RMS) error against random number $(\mathrm{RN})$ range when dose, dose rate and dose + dose rate were used as UV stress mechanisms. When using dose + dose rate, the $\mathrm{RN}$ range for dose rate was varied. For dose, the RN range was remained fixed at 0.00025

\section{Effect of dose and dose rate}

The combined effect of dose and dose rates on the partitioning of biomass in each component of the microbial community was examined. It was considered impractically time-consuming to examine all possible combinations of RN intervals for dose and dose rates. Instead, spot checks of RN intervals were taken over a wide range of values to verify that optimum conditions (lowest RMS errors) occurred close to the optimum conditions when dose or dose rate was acting on its own. Having established this, the RN interval for dose rate was kept fixed at 0.00025 (RN varying between 0 and 0.00025$)$, while that for dose ranged from $1.8 \times 10^{-5}$ $\left(0\right.$ to $\left.1.8 \times 10^{-5}\right)$ to $1.5 \times 10^{-7}\left(0\right.$ to $\left.1.5 \times 10^{-7}\right)$.

Results showed that the lowest RMS of 0.177 was obtained at an $\mathrm{RN}$ range of $1.5 \times 10^{-6}$ (Fig. 3). This value was very close to the $\mathrm{RN}$ value obtained when dose was the only UV stress acting (0 to $\left.1.75 \times 10^{-6}\right)$. Thus, subsequent analyses used $\mathrm{RN}$ between 0 to 0.00025 and 0 to $1.5 \times 10^{-6}$ for dose rate and dose, respectively. Table 3 presents the 8 coefficients obtained for this optimum condition.

One outstanding feature is the considerable variability in the magnitude of the coefficients both within the dose rate and dose categories. The phytoplankton community showed the greatest response to dose rate. For example, at a noon-time erythemal irradiance of $150 \mathrm{~mW} \mathrm{~m}^{-2}$, phytoplankton mortality ( 1 - fuvp) was 0.011 or $1.1 \%$ of the phytoplankton biomass in a 10 min time period centred at solar noon. By contrast, protozoa were most sensitive to dose. A daily dose of $5 \mathrm{~kJ} \mathrm{~m}^{-2}$, typical of cloudless conditions for the study area, would cause a decline in protozoan biomass of approximately $1 \%$.

\section{Model calculations}

\section{Sensitivity to dose and dose rate}

Having obtained the UV stress coefficients (Table 3), the model was used to predict processes occurring within the microbial community. One important issue was the relative importance of the UV stress coefficients in Table 3. To examine the stress coefficients, the model, as described in Eqs. (8) to (14), was applied using the same initial carbon concentrations of phytoplankton, bacteria and protozoa as in the previous section. However, rather than using the measured erythemal irradiance, it was modelled for clear skies and at depths of 1.0, 2.0 and $3.6 \mathrm{~m}$. The procedure was as follows.

The UVSPEC radiative transfer model with the DISORT algorithm was applied for a polar summer atmosphere and latitude of $68.58^{\circ} \mathrm{S}$ (corresponding to Davis Station) for December 15. Results were then convolved by the erythema curve (McKinlay \& Diffey 1987), therefore producing erythemal irradiance. Calculations were performed every $10 \mathrm{~min}$ for a total ozone column of 250 DU. Clear sky irradiance conditions were examined for a $7 \mathrm{~d}$ period, with all days having the same irradiance characteristics. Starting conditions for microbial concentrations were assumed to be the same as in the experiment.

Table 3. Optimum erythemal UV stress coefficients (UVBR: ultraviolet-B radiation) of each microbial component for dose rate (DR), dose (D), partitioning of carbon between protozoa and DOC $\left(C_{\mathrm{P}}\right)$ and threshold of impact on microbial biomass $\left(U V_{\mathrm{T}}\right)$

\begin{tabular}{|ll}
\hline Model term & $\begin{array}{c}\text { Optimum erythemal } \\
\text { UVBR coefficient }\end{array}$ \\
\hline$C_{1 \mathrm{DR}}$ (phytoplankton) & $7.51 \times 10^{-5}\left(\mathrm{~mW} \mathrm{~m}^{-2}\right)^{-1}$ \\
$C_{2 \mathrm{DR}}$ (bacteria) & $1.07 \times 10^{-7}\left(\mathrm{~mW} \mathrm{~m}^{-2}\right)^{-1}$ \\
$C_{3 \mathrm{DR}}$ (protozoa) & $3.36 \times 10^{-4}\left(\mathrm{~mW} \mathrm{~m}^{-2}\right)^{-1}$ \\
$C_{1 \mathrm{D}}$ (phytoplankton) & $2.98 \times 10^{-10}\left(\mathrm{~J} \mathrm{~m}^{-2}\right)^{-1}$ \\
$C_{2 \mathrm{D}}$ (bacteria) & $1.06 \times 10^{-10}\left(\mathrm{~J} \mathrm{~m}^{-2}\right)^{-1}$ \\
$C_{3 \mathrm{D}}$ (protozoa) & $1.490 \times 10^{-5}\left(\mathrm{~J} \mathrm{~m}^{-2}\right)^{-1}$ \\
$C_{\mathrm{P}}$ & 0.322 \\
$U V_{\mathrm{T}}$ & $28.1 \mathrm{~mW} \mathrm{~m}^{-2}$ \\
\hline
\end{tabular}


The UV stress terms, as described in Eqs. (8) to (10), were written as the product of 2 transmission terms $\mathrm{f}_{i j \prime}$ one describing dose rate and the second one dose:

$$
\begin{aligned}
& \text { fuvp }=\exp \left(-c_{1 \mathrm{DR}} U V\right) \exp \left(-C_{1 \mathrm{D}} S\right)=\mathrm{f}_{11} \mathrm{f}_{12} \\
& \text { fuvb }=\exp \left(-C_{2 \mathrm{DR}} U V\right) \exp \left(-C_{2 \mathrm{D}} S\right)=\mathrm{f}_{21} \mathrm{f}_{22} \\
& \text { fuvz }=\exp \left(-C_{3 \mathrm{DR}} U V\right) \exp \left(-C_{3 \mathrm{D}} S\right)=\mathrm{f}_{31} \mathrm{f}_{32}
\end{aligned}
$$

where $i$ in $\mathrm{f}_{i j}$ takes values of 1, 2 and 3 for phytoplankton, bacteria and protozoa, respectively; and $j$ takes the value 1 for dose rate and 2 for dose. At each model iteration, the decline in microbial carbon was partitioned into that derived due to dose and dose rate and summed over $7 \mathrm{~d}$. The following sums were estimated:

$$
\begin{aligned}
& S_{i \mathrm{DR}}=\sum_{t=1}^{\mathrm{N}}\left(1-\mathrm{f}_{i 1}\right) X_{i} \\
& S_{i \mathrm{D}}=\sum_{t=1}^{\mathrm{N}}\left(1-\mathrm{f}_{i 2}\right) X_{i} \\
& S_{i \mathrm{~T}}=\sum_{t=1}^{\mathrm{N}}\left(1-\mathrm{f}_{i 1} \mathrm{f}_{i 2}\right) X_{i}
\end{aligned}
$$

where $\mathrm{D}, \mathrm{DR}$ and $\mathrm{T}$ refer to dose, dose rate and the 2 combined, respectively; and $X$ refers to carbon concentrations. Summation was performed over $10 \mathrm{~min}$ intervals for a total of $7 \mathrm{~d}$, and was normalised with respect to the initial carbon concentration of each element of the microbial community (Table 4). Results showed that the dose rate of erythemal UV caused most of the decline in phytoplankton biomass, while the decline in protozoan biomass was mostly due to dose. Bacteria were affected little by UV.

A second sensitivity test was used to determine the effect of UV stress on the 3 components of the microbial community. The model was run with the same conditions as above, and concentrations at the end of the $7 \mathrm{~d}$ run were noted. The model was then re-run 4 times with the same conditions, except that 1 of 4 UV stress terms was doubled. In light of the above sensitivity results, only dose rate for phytoplankton $\left(C_{1 \mathrm{DR}}\right)$, dose for protozoa $\left(C_{3 \mathrm{D}}\right)$, the partitioning term $C_{\mathrm{P}}$ and the UV threshold term $U V_{\mathrm{T}}$ were examined. Data are presented as fractions of the original carbon concentrations predicted by the model with the original unaltered UV stress terms (Fig. 4).

Doubling the erythemal UV dose rate $(2 \times$ $\left.c_{1 \mathrm{DR}}\right)$ caused the biomass of phytoplankton to drop markedly, the extent of the decline decreasing approximately linearly with increased depth (Fig. 4A). In contrast, protozoan biomass increased at $\geq 1 \mathrm{~m}$ depth and only declined at $0.2 \mathrm{~m}$, while bacterial biomass was
Table 4. UV-induced decline in biomass of each microbial component normalised against its initial carbon concentration $\left(X_{0 i}\right) . S_{i \mathrm{DR}}, S_{i \mathrm{D}}$ and $S_{\mathrm{iT}}$ refer to mortality due to UV dose rate, dose and total UV stress (dose + dose rate), respectively

\begin{tabular}{|lclc|}
\hline & $S_{i \mathrm{DR}} / X_{0 i}$ & $S_{i \mathrm{D}} / X_{0 i}$ & $S_{i \mathrm{~T}} / X_{0 i}$ \\
\hline Phytoplankton & 0.742 & 0.0003 & 0.742 \\
Bacteria & 0.002 & 0.0002 & 0.002 \\
Protozoa & 0.001 & 7.307 & 7.309 \\
\hline
\end{tabular}

reduced by around $30 \%$ at $\leq 2 \mathrm{~m}$ depth (Fig. 4A). Doubling the UV dose $\left(2 \times c_{3 \mathrm{D}}\right)$ had little effect on the biomass of phytoplankton and bacteria, but approximately halved protozoan biomass at $\leq 2 \mathrm{~m}$ depth (Fig. 4B). Doubling the term partitioning carbon between protozoa and bacteria $\left(2 \times C_{\mathrm{P}}\right)$ increased concentrations of protozoan carbon approximately 1.8 times, but more than halved bacterial biomass at $\leq 2 \mathrm{~m}$ depth (Fig. 4C). Reducing the UV sensitivity of the marine microbes by doubling the threshold for UVinduced impact $\left(2 \times U V_{\mathrm{T}}\right)$ caused the biomass of phytoplankton to increase with decreasing depth, except at $0.2 \mathrm{~m}$ depth, where some inhibition of phytoplankton biomass was observed (Fig. 4D). The protozoan response to doubling $U V_{\mathrm{T}}$ was opposite that of phytoplankton biomass, markedly increasing at $0.2 \mathrm{~m}$ depth,

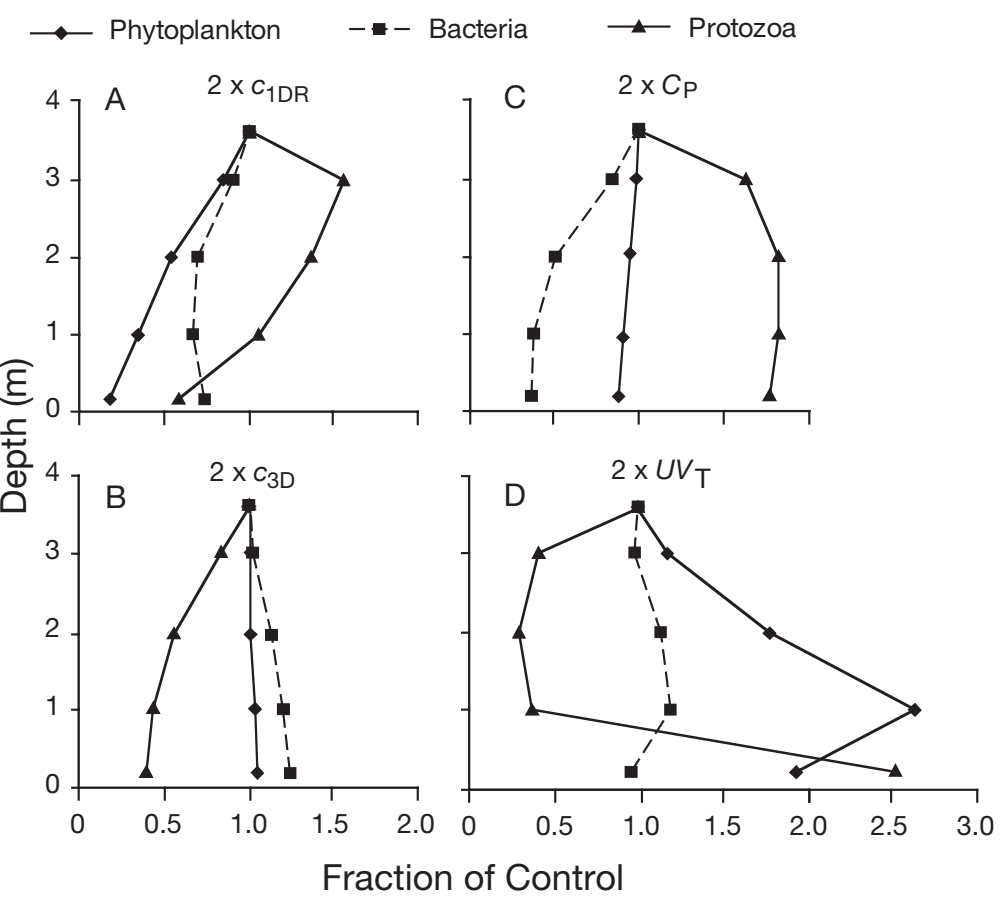

Fig. 4. Change in system components for a doubling of: (A) phytoplankton dose rate $C_{1 \mathrm{DR}}$, (B) protozoan dose $C_{3 \mathrm{D} r}$ (C) partitioning term $C_{\mathrm{P}}$ and (D) threshold level $U V_{\mathrm{T}}$. Data are expressed as a fraction of model prediction without perturbation 

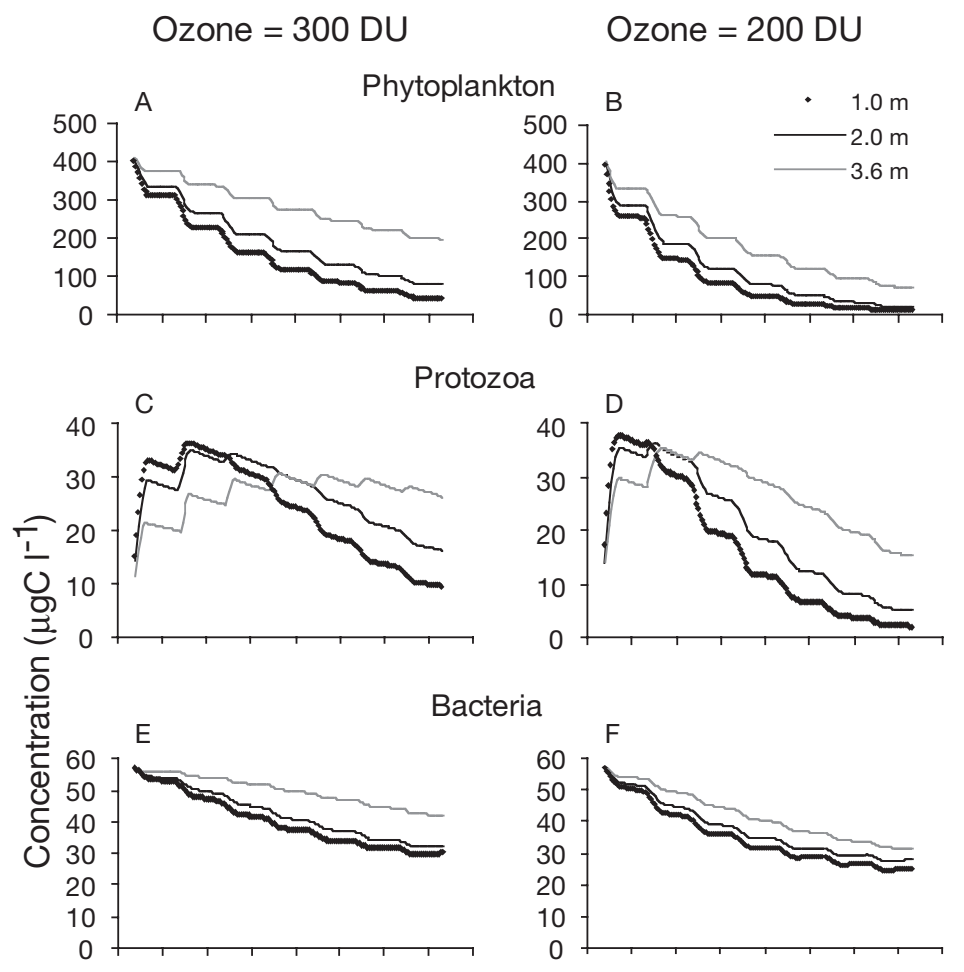

Bacteria
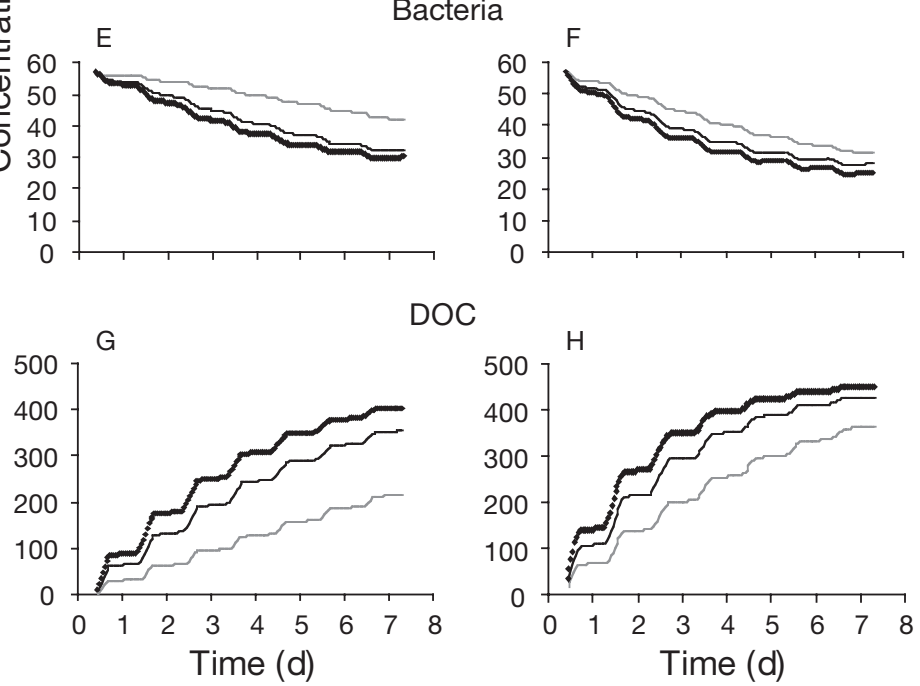

DOC

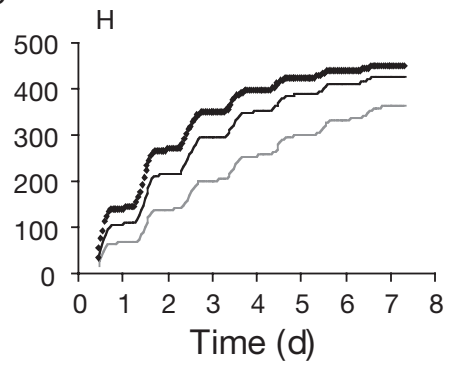

Fig. 5. Model output for 2 different column ozone concentrations (200 and $300 \mathrm{DU})$ and 3 depths $(1.0,2.0$ and $3.6 \mathrm{~m}$ ) for phytoplankton $(\mathrm{A}, \mathrm{B})$, protozoa $(\mathrm{C}, \mathrm{D})$, bacteria $(\mathrm{E}, \mathrm{F})$ and dissolved organic carbon (DOC) $(\mathrm{G}, \mathrm{H})$

but declining around $70 \%$ at greater depth (Fig. 4D). Bacterial biomass did not change substantially due to doubling of dose, $C_{\mathrm{P}}$, or $U V_{\mathrm{T}}$ (Fig. $4 \mathrm{~B}$ to D).

\section{Sensitivity to ozone}

The model was run with the standard set of conditions with the exception that total column ozone used values of 200 and 300 DU, covering 2 extreme cases at the height of the summer solstice. Concentrations for the 3 microbial communities were determined over a model run of $7 \mathrm{~d}$ (Fig. 5).

Phytoplankton biomass at ozone concentrations equal to 200 DU decreased with time at all depths, with $1.0 \mathrm{~m}$ concentrations exhibiting the largest decrease
(Fig. 5B). At $\mathrm{O}_{3}$ equal to $300 \mathrm{DU}$ there were much smaller changes in phytoplankton concentrations at 2.0 and $3.6 \mathrm{~m}$ (Fig. 5A).

Protozoa were the only element of the marine microbial community that were enhanced by exposure to UVR, the peak in their biomass being very pronounced at shallow depths and low ozone during the first few days (Fig. 5D). However, prolonged exposure in shallow waters caused their concentrations to decline, reflecting the sensitivity of protozoa to UV dose. At $3.6 \mathrm{~m}$ depth and $\mathrm{O}_{3}$ equal to $300 \mathrm{DU}$, there was no evidence of a peak in protozoan concentrations (Fig. 5C).

Bacterial concentrations exhibited a smaller rate of change over time than either phytoplankton or protozoa. The curves were quite similar in the 2 ozone scenarios examined (Fig. 5E,F).

Declining depth and lower ozone (or $\mathrm{O}_{3}$ ) concentration caused DOC to increase (Fig. 5G,H). The rate of increase over time was low at $3.6 \mathrm{~m}$ depth under 300 DU of ozone, but increased rapidly at shallower depths and at lower ozone concentrations, where UV-induced mortality of phytoplankton was high (Fig. 5A,B).

\section{Individual responses}

Multiple linear regression of the biomass of individual taxa or groups against characteristics of the light climate irradiance showed large variation between the components of the phytoplankton community. All correlation coefficients, each with 16 degrees of freedom, were significant at the $95 \%$ level of confidence, as were the regression coefficients shown in bold (Table 5). Species were categorised after Davidson \& Belbin (2002) as inhibited, unchanged, or enhanced by exposure to UV. UV dose rate $\left(\beta_{3}\right)$ caused a decline in the biomass in 4 of the 5 UV-inhibited phytoplankton taxa, namely, in Fragillariopsis curta (Van Heurck) Krieger and F. cylindrus (Grunow) Krieger, which were grouped as they could not be discriminated in girdle view, Pseudonitzschia subcurvata Hasle, Thalassiosira ambigua Kozlova and Fragillariopsis pseudonana (Hasle) Krieger (Table 5). In contrast, while the autotrophic nanoflagellate biomass was inhibited overall, it significantly increased in response to both dose and dose rate. The photosynthesis coefficient for this species was negative, indicating photosensitivity. However, the coefficient was not statistically significant, and it is likely that more samples would be needed to establish some degree of confidence. Photosynthesis was positive and significant in 2 out of the 5 inhibited species, and contributed to 
Table 5. Results of multiple linear regression between carbon concentration and UVR for each of the phytoplankton taxa or groups, namely, other diatom species (Other diat.), Fragillariopsis curta and F. cylindrus grouped (F. curta/cyl.), Pseudonitzschia subcurvata (P. subc.), Thalassiosira ambigua (T. ambigua), autotrophic nanoflagellates (Auto. flag.), autotrophic dinoflagellates (Auto. dinos.), Fragillariopsis pseudonana (F. pseud.), Nitzschia glaciei (N. glac.) and Chaetoceros simplex (C. simp.) and whether the biomass of each taxa was enhanced (e), inhibited (i), or unchanged (u). $U V_{\mathrm{T}}$ is the UVR threshold, $\mathrm{r}$ is the regression statistic for $16 \mathrm{df}, \beta_{0}$ to $\beta_{3}$ are multiple regression coefficients for the constant, photosynthesis, dose and dose rate, respectively. Regression statistics presented in bold are significant $(\mathrm{p}<0.05) . T_{0}$ conc. indicates the biomass of each species at the start of the experiment

\begin{tabular}{|lcccccccc|}
\hline & Effect & $\begin{array}{c}U V_{\mathrm{T}} \\
\left(\mathrm{mW} \mathrm{m}^{-2}\right)\end{array}$ & $\mathrm{r}$ & $\beta_{0}$ & $\beta_{1}$ & $\beta_{2}$ & $\beta_{3}$ & $\begin{array}{c}T_{0} \text { conc. } \\
\left(\mu \mathrm{g} \mathrm{C} \mathrm{m} \mathrm{m}^{-3}\right)\end{array}$ \\
\hline Other diat & $\mathrm{u}$ & 32 & 0.64 & $\mathbf{8 3 . 6 1 8}$ & 5.575 & $\mathbf{- 1 3 . 8 8}$ & 0.447 & 288.0 \\
F. curta/cyl. & $\mathrm{i}$ & 40 & 0.84 & $\mathbf{1 9 2 . 1 5 0}$ & $\mathbf{8 . 2 5 8}$ & -3.429 & $\mathbf{- 0 . 7 6}$ & 129.0 \\
P. subc. & $\mathrm{i}$ & 48 & 0.74 & $\mathbf{1 . 8 6 9}$ & 0.046 & -0.076 & $\mathbf{- 0 . 0 1 9}$ & 11.3 \\
T. ambigua & $\mathrm{i}$ & 24 & 0.69 & $\mathbf{5 . 0 1 8}$ & $\mathbf{0 . 9 6 6}$ & -0.022 & $\mathbf{- 0 . 0 3 3}$ & 10.4 \\
Auto. flag. & $\mathrm{i}$ & 16 & 0.82 & $\mathbf{1 0 . 7 2 8}$ & -1.398 & $\mathbf{0 . 0 5 7}$ & $\mathbf{0 . 0 5 0}$ & 2.72 \\
Auto.dinos. & $\mathrm{e}$ & 48 & 0.65 & $\mathbf{2 . 0 7 7}$ & -0.349 & -0.185 & $\mathbf{0 . 0 5 5}$ & 1.9 \\
F. pseud. & $\mathrm{i}$ & 48 & 0.67 & $\mathbf{1 . 1 5 1}$ & -0.021 & 0.0219 & $\mathbf{- 0 . 0 0 7}$ & 1.7 \\
N. glac. & $\mathrm{e}$ & 40 & 0.57 & $\mathbf{8 . 6 7 0}$ & -1.662 & -0.600 & 0.142 & 0.6 \\
C. simp. & $\mathrm{e}$ & 64 & 0.58 & $\mathbf{0 . 3 1 6}$ & $\mathbf{- 0 . 0 2 3}$ & $\mathbf{0 . 0 2 3}$ & $\mathbf{- 0 . 0 0 3}$ & 0.06 \\
\hline
\end{tabular}

increasing their biomass. The coefficient was not significant in 3 other species, and again more samples are needed to establish statistical confidence.

Factors responsible for the UV-induced enhancement of species were less clear. Dose rate had a small but significant negative effect on the biomass of Chaetoceros simplex Ostenfeld, but enhanced the biomass of autotrophic dinoflagellates. Dose counteracted the effect of dose rate in these 2 species, as it was positive for C. simplex but negative, although not significant, for autotrophic dinoflagellates. The third enhanced species, Navicula glaciei Van Heurck, did not show any significant coefficients other than the constant. Other diatoms, whose biomass was unchanged by exposure to UV, showed a negative sensitivity to dose that was significant, but dose rate and photosynthesis were not.

The threshold values for UV-induced effects of the biomass of each phytoplankton species $\left(U V_{\mathrm{T}}\right)$ varied greatly, and ranged from $16 \mathrm{~mW} \mathrm{~m}^{-2}$ for autotrophic nanoflagellates to a maximum of $64 \mathrm{~mW} \mathrm{~m}^{-2}$ for Chaetoceros simplex. Fragillariopsis curta/cylindrus made up a majority of the phytoplankton carbon concentrations (discounting the inactive other diatoms), and its threshold value of $40 \mathrm{~mW} \mathrm{~m}^{-2}$ was in the middle of the range of estimated values, as was the bulk threshold value of $28 \mathrm{~mW} \mathrm{~m}^{-2}$. There was also some indication that UV-enhanced species have higher biologically effective UV thresholds. The highest threshold of $64 \mathrm{~mW} \mathrm{~m}^{-2}$ was obtained for the enhanced species C. simplex, while the 2 lowest thresholds occurred for autotrophic nanoflagellates or Thalassiosira ambigua, which were inhibited by UV. Average values also favour the hypothesis $\left(35 \mathrm{~mW} \mathrm{~m}^{-2}\right.$ for inhibited vs. $51 \mathrm{~mW} \mathrm{~m}^{-2}$ for enhanced). However, more samples are needed to produce significant average differences.

\section{DISCUSSION}

Few studies have addressed UV-induced changes in the dynamics of natural microbial assemblages, and their findings vary greatly (Keller et al. 1997a,b, Laurion et al. 1998, Mostajir et al. 1999, Sommaruga et al. 1999, Davidson \& van der Heijden 2000, Davidson \& Belbin 2002). To our knowledge, the only reports of community-level effects of UVBR on entire natural communities of Antarctic marine microbes exposed to ambient solar UV are those we have performed (Davidson \& van der Heijden 2000, Davidson \& Belbin 2002). Here, we have modelled each microbial component (phytoplankton, bacteria and protozoa) together with DOC to examine the bulk responses of microbial components to UV exposure and the ramifications for interactions between these components.

\section{Modelling}

The modelling followed here compromises between 2 extreme approaches. At one extreme a relationship may be developed between carbon concentration in the 3 microbial components and UVR. These may be linked using simple linear regression analysis to produce a set of empirical coefficients. Assuming an acceptable level of statistical significance, these relationships may be used to trace the changes in microbial biomass in the system in response to PAR- and UVinduced stress. However, there are limitations to a purely statistical approach. Most importantly, it fails to capture the important mechanisms occurring between biological components such as grazing, the partitioning of phytoplankton mortality by the system, or even the response of the system to UV dose or UV dose rate. 
At the other end of the spectrum are detailed processoriented models that trace the flow of carbon, nutrients, dissolved organic matter and other chemical constituents in each of the system components (Moloney \& Field 1991, Lancelot et al. 1997). Such models are very comprehensive, but require data exceeding those collected in our experiment. Nevertheless, they are attractive in that they provide information on the various processes involved and the interactions between the microbial components.

We incorporated features of both of these approaches by explicitly describing the change in carbon in each of the system components. Grazing terms are taken from the literature. UV-induced mortality and the changes in biomass and respiration of carbon are obtained using empirical coefficients determined by minimising the error between model and measured carbon concentrations.

UV stress terms affected the standing stock of phytoplankton, bacteria and protozoa directly, as well as photosynthesis by phytoplankton. The types of stress were described by 9 coefficients, the values of which were obtained using an iterative procedure, with values being accepted if they lowered the error between modelled and measured carbon concentrations.

One notable feature of the model is the way phytoplankton mortality has been treated. The standing stock directly depleted by UVR was partitioned between protozoan grazing and contribution to the DOC pool. The partitioning was done via an empirical term, $C_{\mathrm{P}}$, which replaces the more realistic, but presently unknown physical interaction by which protozoa graze on dead phytoplankton.

\section{Bulk responses}

At 0.0115 the phytoplankton productivity coefficient $a_{1}$ was low in comparison with the mean rates of phytoplankton production (0.06) in Lancelot et al. (1997), even accounting for photoinhibition by PAR and grazing by protozoa. Published literature indicates that nutrients do not limit phytoplankton growth in Antarctic coastal waters (e.g. Holm-Hansen et al. 1994, Odate \& Fukuchi 1995). Growth of phytoplankton was observed at equivalent depths $>2.0 \mathrm{~m}$, and carbon concentrations approximately doubled over the $10 \mathrm{~d}$ of exposure and post-UV incubation (Davidson \& Belbin 2002). Thus, it seems unlikely that nutrient depletion inhibited the growth of phytoplankton. We found that culture conditions favoured the growth of small phytoplankton including Fragillariopsis curta/cylindrus and Navicula glaciei at the expense of large autotrophic dinoflagellates and species of diatoms such as Chaetoceros, Dactylosolens and Thalassiosira (Davidson \&
Belbin 2002). The resulting culture-induced change in species composition irrespective of the light treatment would limit increases in phytoplankton biomass in our experiments.

Both UV dose and dose rate were included as stress terms in the model, which was run with each stress term operating exclusively, as well as with the 2 terms combined. In each model run the RN generator was restricted to a particular range and the model RMS error was noted after 2000 iterations. This procedure ensured that optimum coefficients minimising RMS errors were obtained for dose, dose rate and a combination of both. Results showed that the lowest error $(17.7 \%)$ was obtained with the combination of dose and dose rate as stress terms operating on all 3 components. Results showed that only 2 out of the 6 possible coefficients lowered the RMS error significantly: dose rate for phytoplankton and dose for protozoa.

The dependence of phytoplankton biomass on UV dose rate suggests that their UV tolerance is largely determined by the equilibrium between the rates of UV-induced damage and repair. Marine microalgae possess a diverse capacity to avoid, sustain and repair UV-induced damage (e.g. reviews by Davidson 1998, 2006, Buma et al. 2000, Vernet 2000, Banaszak 2003, Villafañe et al. 2003). Most UV-tolerance mechanisms, including DNA repair, antioxidant activity and the repair or resynthesis of membrane components, chromophore molecules, photosynthetic pigments and proteins such as enzymes, hormones and histones, are rate limited (Tevini 1993, Banaszak 2003, Villafañe et al. 2003). Any increase in UV dose rate would increase the rate of UV-induced damage that, if beyond the rate of repair, would lead to accumulation of damage that would reduce growth and survival.

Few studies differentiate between the effects of UV dose and dose rate. Field and laboratory studies of marine phytoplankton have shown that UV-induced photoinhibition is related to the rate of UV exposure (Behrenfeld et al. 1993, Lesser et al. 1994). In contrast, Neale et al. (1998a,b), working with natural Antarctic phytoplankton assemblages, found no evidence of photorepair and described the inhibition as a function of cumulative exposure. However, such studies examine the acute affects of UV exposure on photosynthetic rates, were conducted over periods of hours rather than days or weeks and are not directly comparable to our study. Thus, our finding that phytoplankton biomass was largely determined by UV dose rate agrees with the ratelimitation of tolerance mechanisms and, though seldom explicitly stated, is supported in the literature.

Although we found that protozoan biomass was reduced by UV dose, it peaked when exposed to high UV for $\leq 4$ d. Similar to Sommaruga et al. (1999), the protozoa in our study showed a high tolerance to UV 
exposure. The peak in protozoa coincided with high phytoplankton mortality and an accumulation of DOC that probably increased bacterial growth (Davidson \& van der Heijden 2000, Davidson \& Belbin 2002). This was likely due to indirect, community-level effects of UV exposure that increased the nutrition available to protozoa and bacteria, thereby compensating for any inhibitory effect of UVR on their biomass. Similar to previous studies (Herndl et al. 1993, Jeffrey et al. 1996), Davidson \& van der Heijden (2000) reported that bacterial growth was inhibited by UVR during exposure. However, they found bacterial growth during post-UV incubation was higher in treatments that had received high UV irradiances. As our model was based on post-UV-incubated samples it did not resolve UV-induced inhibition of bacterial growth during UV exposure. The decline in protozoa following $>4 \mathrm{~d}$ of exposure, which led to the dose-related response of protozoa in our model, may have been due to UVinduced inhibition following the declining impact of UV on the phytoplankton and reduced growth of bacteria and DOC.

We found a threshold value of $28.1 \mathrm{~mW} \mathrm{~m}^{-2}$ erythemal UVR, equating to a noon-time irradiance at $3.6 \mathrm{~m}$ depth, below which there was no increase in phytoplankton mortality. Little evidence is available in the literature regarding thresholds of UV exposure. Helbling et al. (1996) reported a threshold of integrated UV (295 to $385 \mathrm{~nm}$ ) for inhibition of primary production of $5.0 \mathrm{~W} \mathrm{~m}^{-2}$, which, in the absence of ozone depletion in clear Antarctic waters, equated to a water column depth of around $15 \mathrm{~m}$. In contrast, Booth et al. (1997) reported $0.5 \mathrm{~W} \mathrm{~m}^{-2}$ for UVB and $10 \mathrm{~W} \mathrm{~m}^{-2}$ for UVA, while Helbling et al. (1996) found there was no threshold for inhibition of primary production for Arctic phytoplankton from a deep mixed layer. Behrenfeld et al. (1993) grouped different phytoplankton taxa to study the effect of UV dose on carbon fixation rates. They commented that the scatter in the relationship may hide differences in the tolerance and thresholds of the various phytoplankton taxa that were grouped. Variations in threshold UVR reported in the literature reflect differences in the metabolic processes studied and thus the sensitivity of the target chromophores to UV damage, the light history of cells and the UV tolerance of the species exposed to UVR. Species-specific responses to various features of ambient solar radiation are discussed in more detail below.

\section{Sensitivity tests}

Having obtained the optimum coefficients, a test was performed to determine the ability of each of the $6 \mathrm{UV}$ stress terms ( 3 for dose and 3 for dose rate) to affect the microbial standing stock. For each iteration of the model, the mortality corresponding to each stress term was summed and the total cumulative mortality was expressed as a fraction of the microbial community at the start of the experiment. These results showed overwhelmingly that dose rate affects phytoplankton, while dose affects protozoa. Bacteria did not respond to either dose or dose rate.

A second test determined the ability of each important UV stress term to affect total carbon concentration in various system components. One of 4 stress terms $\left(C_{1 \mathrm{DR}}, C_{3 \mathrm{D}}, C_{\mathrm{P}}\right.$ and $\left.U V_{\mathrm{T}}\right)$ was doubled, while the rest of the terms were kept constant. Final carbon concentrations in each system component were then compared with predicted final carbon concentrations with undisturbed coefficients. Results showed that the entire system is most sensitive to changes in phytoplankton dose rate coefficients, with surface concentrations of phytoplankton approaching zero with a doubling of the coefficient. As phytoplankton comprised around $85 \%$ of all microbial carbon, changes in UV dose rate most affected microbial biomass. These results indicate the need to obtain further estimates for this coefficient, given its strong impact on modelled phytoplankton and protozoa. The threshold for UV-induced effects $\left(U V_{\mathrm{T}}\right)$ also strongly influences concentrations of phytoplankton and protozoa. The other 2 terms, $C_{\mathrm{P}}$ and $C_{3 \mathrm{D}}$, were least important in influencing microbial biomass and, in the case of $C_{3 \mathrm{D}}$, were restricted to protozoan concentrations.

Our results indicate that the impact of increasing dose or dose rate on the microbial community is mainly restricted to the system component that is being acted upon (either phytoplankton or protozoa). A more diverse impact occurs when the threshold $U V_{\mathrm{T}}$ is increased. Phytoplankton stocks increase significantly and near-surface protozoa will also increase due to grazing. However, at greater depths, UV-induced mortality of phytoplankton is low and this limited protozoa growth.

The model showed that high ozone levels create a more stable, slowly varying system. After $7 \mathrm{~d}$, phytoplankton concentrations are still appreciable, even at lesser depths, where the UV irradiance is expected to be higher. This slowly varying time scale is similar to that occurring with changing weather systems and/or advective transport. Thus, it is difficult to isolate the effect of UV stress from other processes.

\section{Individual responses}

Our results clearly illustrate species-specific differences in the response to the same radiation stimuli. Different species and life-cycle stages of microalgae 
differ greatly in their tolerance of UVB exposure (Karentz et al. 1991, Marchant et al. 1991, Smith et al. 1992, Davidson et al. 1994, 1996, Hannach \& Sigleo 1998, Buma et al. 2000, Davidson \& Belbin 2002). The nature and magnitude of the UV-induced changes in marine communities appear to be due to the sensitivity of the individual species comprising the community and the extent to which these species are key determinants of the community structure and function (Davidson \& Belbin 2002). Thus, it is not valid to extrapolate from our results to the responses of Antarctic marine microbial communities in general. Within these constraints, results showed that after $7 \mathrm{~d}$ exposure there was a substantial transfer of biomass from phytoplankton to dissolved organic matter and that this transfer was accelerated with decreasing ozone concentration.

Results from the statistical analysis of individual phytoplankton species cast some light on the bulk behaviour of the ecosystem. Four of the 5 inhibited species were sensitive to dose rate. In particular, Fragillariopsis curta/cylindrus, which dominated the phytoplankton biomass, had a sensitivity to dose rate and a UV threshold similar to that of the bulk phytoplankton. However, there was considerable variability among enhanced species, as their biomass increased to varying degrees in response to UV dose rate or dose; these responses ameliorated photoinhibition by PAR. Whether this was due to the direct benefits of UV exposure on these taxa or whether their high tolerance allowed them to out-compete less tolerant taxa remains unclear. However, there is evidence that UVR can benefit some phytoplankton (Davidson \& Marchant 1994, Prézelin et al. 2000). There was also considerable variability in the UV threshold of UV exposure among individual phytoplankton taxa and groups. The decline in some taxa and increase in others are indicative of a community-level acclimation to UV exposure that favours UV-resistant organisms and mitigates against UV exposure (Vernet 2000, Villafañe et al. 2003). Clearly, a bulk model cannot reproduce these smaller effects.

The choice of independent variables in a regression model always implies a degree of subjectivity. While our results showed species-specific differences to the same UVR, the question remains as to what physical property of the species and/or what radiation property causes these differences. These questions could be answered by detailed physical/statistical models of individual species, followed by some mechanism of integrating the responses of individuals to determine community-level responses.

In many ways the approach followed in this study is similar to that followed in multiple linear regression analysis, in that coefficients were derived following a minimisation procedure between measured and predicted variables. As mentioned earlier, this imposes limitations on the general applicability of these results. Nevertheless, insight can be gained into the nature and character of the UV stress by employing a detailed description of the biomass transfer. On a qualitative basis we conclude that phytoplankton primarily respond to dose rate, protozoa to dose and that bacteria are insensitive to both. Recent experiments conducted at Davis Station that directly measure DOC, particulate organic carbon and rates of phytoplankton and bacterial production over a range of communities should help determine whether the coefficients derived in this study are representative of a range of natural microbial communities in Antarctic waters.

Our results indicate that enhancement of UVBR increases the exposure of phytoplankton to irradiances above the threshold of UV-induced damage in nearsurface Antarctic waters, reducing the sequestration of carbon, and increases heterotrophic biomass, which likely increases the respiration and ventilation of $\mathrm{CO}_{2}$ into the atmosphere. Thus, ozone depletion over Antarctica is likely to reduce the magnitude of the biological pump, thereby exacerbating accumulation of greenhouse gases in the atmosphere.

Acknowledgements. We thank H. Marchant, S. Wright and A. Buma for their constructive criticism of the manuscript.

\section{LITERATURE CITED}

Archer SD, Leakey RJG. Burkhill PH, Sleigh MA, Allpeby CJ (1996) Microbial ecology of sea ice at a coastal Antarctic site: community composition biomass and temporal change. Mar Ecol Prog Ser 135:179-195

Banaszak AT (2003) Photoprotective physiological and biochemical responses of aquatic organisms. In: de Mora S, Demers $S$, Vernet $M$ (eds) The effects of UV radiation in the marine environment. Cambridge Environmental Chemistry Series, Vol 10. Cambridge University Press, Cambridge, p 329-356

Behrenfeld MJ, Chapmen JW, Hardy JTY, Lee H II (1993) Is there a common response to ultraviolet-B radiation by marine phytoplankton? Mar Ecol Prog Ser 102:59-68

Bjørnsen PK, Kuparinen J (1991) Determination of bacterioplankton biomass, net production and growth efficiency in the Southern Ocean. Mar Ecol Prog Ser 71:185-194

Booth CR, Morrow JH, Coohill TP, Cullen JJ and 9 others (1997) Impacts of solar UVR on aquatic microorganisms. Photochem Photobiol 65:252-269

Børsheim KY, Bratak G (1987) Cell volume to cell carbon conversion factors for bactivorous Monas sp. enriched from seawater. Mar Ecol Prog Ser 36:171-175

Bothwell ML, Sherbot D, Pollock CM (1994) Ecosystem response to solar ultraviolet-B radiation: influence of trophic level interactions. Science 265:97-100

Buma AGJ, Boelen P, Jeffrey WH (2000) UVR-induced damage in aquatic organisms. In: de Mora S, Demers S, Vernet $M$ (eds) The effects of UV radiation in the marine environment. Cambridge Environmental Chemistry Series, Vol 10. Cambridge University Press, Cambridge, p 291-327 
Caron DA, Dam HG, Kremer P, Lessard EJ and 6 others (1995) The contribution of microorganisms to particulate carbon and nitrogen surface waters or the Sargasso Sea near Bermuda. Deep-Sea Res 42:943-972

Davidson AT (1998) The impact of UVB radiation on marine plankton. Mutation Res 422:119-129

Davidson AT (2006) Effects of ultraviolet radiation on microalgal growth, survival and production. In: Rao SDV (ed) Algal cultures, analogues of blooms and applications. Science Publishers, Enfield, NH

Davidson AT, Belbin L (2002) Exposure of Antarctic marine microbial communities to ambient UV radiation: effects on the marine microbial community. Aquat Microb Ecol 27: 159-174

Davidson AT, Marchant HJ (1992) Protist abundance and carbon concentration during a Phaeocystis-dominated bloom at an Antarctic coastal site. Polar Biol 12:387-395

Davidson AT, Marchant HJ (1994) Comparative impact of in situ UV exposure on productivity, growth and survival of Antarctic Phaeocystis and diatoms. Proc NIPR Symp Polar Biol 7:53-69

Davidson AT, van der Heijden A (2000) Exposure of natural Antarctic marine microbial assemblages to ambient UV radiation: effects on bacterioplankton. Aquat Microb Ecol 21:257-264

Davidson AT, Bramich D, Marchant HJ, McMinn A (1994) Effects of UV-B irradiation on growth and survival of Antarctic marine diatoms. Mar Biol 119:507-515

Davidson AT, Marchant HJ, de la Mare WK (1996) Natural UVB exposure changes the species composition of Antarctic phytoplankton in mixed culture. Aquat Microb Ecol 10: 299-305

Dehairs F, Geoyens L, Stroobants N, Mathot S (1992) Elemental composition in the Weddell-Scotia confluence area during spring and summer 1988 (EPOS Leg 2). Polar Biol 12:25-33

Frederick JE, Lubin D (1994) Solar ultraviolet radiation at Palmer Station, Antarctica. In: Weiler CS, Penhale PA (eds) Ultraviolet radiation in Antarctica: measurements and biological effects. Antarctic Research Series, Vol 62. American Geophysical Union, Washington, DC, p 43-52

Hannach G, Sigleo AC (1998) Photoinduction of UV-absorbing compounds in six species of marine phytoplankton. Mar Ecol Prog Ser 174:207-222

Helbling EW, Eilertsen HC, Villafañe VE, Holm-Hansen O (1996) Effects of UV radiation on post-bloom phytoplankton populations in Kvalsund, North Norway. J Photochem Photobiol 33:255-259

Herndl GJ, Müller-Niklas G, Frick J (1993) Major role of ultraviolet-B in controlling bacterioplankton in the surface layer of the ocean. Nature 361:717-719

Holm-Hansen O, Amos AF, Silva NS, Villafañe V, Helbling EW (1994) In situ evidence for nutrient limitation of phytoplankton in pelagic Antarctic waters. Antarct Sci 6: 315-324

Jeffrey WH, Pledger RJ, Aas P, Hager S, Coffin RB, Von Haven R, Mitchell DL (1996) Diel and depth profiles of DNA photodamage in bacterioplankton exposed to ambient solar ultraviolet radiation. Mar Ecol Prog Ser 137: 283-291

Jeffrey WH, Kase JP, Wilhelm SW (2000) UV radiation effects on heterotrophic bacterioplankton and viruses in marine ecosystems. In: de Mora S, Demers S, Vernet M (eds) The effects of UV radiation in the marine environment. Cambridge Environmental Chemistry Series, Vol 10. Cambridge University Press, Cambridge, p 206-236

Jones AE, Shanklin JD (1995) Continued decline of ozone over Halley, Antarctica, since 1985. Nature 376:409-411

Karentz D, Cleaver JE, Mitchell DL (1991) Cell survival characteristics and molecular responses of Antarctic phytoplankton to ultraviolet-B radiation. J Phycol 27:326-341

Keller A, Hargraves P, Jeon H, Klein-Macphee G, Klos E, Oviatt C, Zhang J (1997a) Ultraviolet-B radiation enhancement does not affect marine trophic levels during a winter-spring bloom. Ecoscience 4:129-139

Keller A, Hargraves P, Jeon H, Klein-Macphee G, Klos E, Oviatt C, Zhang J (1997b) Effects of ultraviolet-B enhancement on marine trophic levels in a stratified coastal system. Mar Biol 130:277-287

Kerr RA (1998) Deep chill triggers record ozone hole. Science 282:391

Lancelot C, Becquevort S, Menon P, Mathot S, Dandois JM (1997) Ecological modelling of the planktonic microbial food-web. Research Contract A3/11/001, Serial Number ANTAR/97/3, Federal Office for Scientific, Technical and Cultural Affairs (OSTC), Brussels, p 1-78

Laurion I, Lean DRS, Vincent WF (1998) UVB effects on a phytoplankton community: results from a large-scale enclosure assay. Aquat Microb Ecol 16:189-198

Lesser MP, Cullen JJ, Neale PJ (1994) Carbon uptake in a marine diatom during acute exposure to ultraviolet radiation: relative importance of damage and repair. J Phycol 30:183-192

Madronich S (1995) The radiation equation. Nature 377: 682-683

Madronich S, McKenzie RL, Björn LO, Caldwell MM (1998) Changes in biologically active ultraviolet radiation reaching the Earth's surface. J Photochem Photobiol 46: $5-19$

Marchant HJ (1997) Impacts of ozone depletion on Antarctic organisms. In: Battaglia B, Valencia J, Walton DWH (eds) Antarctic communities: species, structure and survival. Proceedings of the 6th SCAR biology symposium. Cambridge University Press, Cambridge, p 367-374

Marchant HJ, Davidson AT, Kelly GJ (1991) UV-B protecting pigments in the marine alga Phaeocystis pouchetii from Antarctica. Mar Biol 109:391-395

McKinlay AF, Diffey BL (1987) A reference action spectrum for ultraviolet induced erythema in human skin. CIE J 6: $17-22$

Moloney CL, Field JG (1991) Modelling carbon and nitrogen flows in a microbial plankton community. In: Reid PC, Turley CM, Burkill PH (eds) Protozoa and their role in marine processes. NATO ASI Series G25, Springer-Verlag, Berlin, p 443-474

Montagnes DJS, Berges JA, Harrison PJ, Taylor FJR (1994) Estimating carbon, nitrogen, protein, and chlorophyll a from volume in marine phytoplankton. Limnol Oceanogr 39:1044-1060

Mostajir JB, Demers S, de Mora SJ, Belzile C and 6 others (1999) Experimental test of the effect of ultraviolet-B radiation in a planktonic community. Limnol Oceanogr 44: 586-596

Mostajir JB, Demers S, de Mora SJ, Bukata RP, Jerome JH (2000) Implications of UV radiation for the food web structure and consequence for carbon flow. In: de Mora S, Demers S, Vernet $M$ (eds) The effects of UV radiation in the marine environment. Cambridge Environmental Chemistry Series, Vol 10. Cambridge University Press, Cambridge, p 310-320

Neale PJ, Cullen JJ, Davis RF (1998a) Inhibition of marine phytoplankton by ultraviolet radiation: variable sensitivity of phytoplankton in the Weddell-Scotia Confluence during austral spring, Limnol Oceanogr 43:433-448 
Neale PJ, Davis RF, Cullen JJ (1998b) Interactive effects of ozone depletion and vertical mixing on photosynthesis of Antarctic phytoplankton. Nature 392:585-589

Odate T, Fukuchi M (1995) Physical and chemical properties of surface water in the Southern Ocean in summer 1991/92. Proc NIPR Symp Polar Biol 8:77-85

Prézelin BB, Kerfoot J, Gorga J, McGovern T, Robiart J (2000) In situ spectral response of phytoplankton communities to regional and seasonal variability in solar UV radiation off coastal California: SUPACC 1998. In: Associated workshop to the SPARC 2000 impacts of UV radiation on aquatic and terrestrial ecosystems. Mar del Plata, Argentina, p 29 (abstract)

Putt M, Stoeker DK (1989) An experimentally determined carbon:volume ratio for marine 'oligotrichous' ciliates from estuarine and coastal waters. Limnol Oceanogr 34: $1097-1103$

Smith RC, Prézelin BB, Baker KS, Bidigare RR and 9 others (1992) Ozone depletion: ultraviolet radiation and phytoplankton biology in Antarctic waters. Science 255: 952-959

Sommaruga R, Sattler B, Oberleiter A, Wille A and 8 others (1999) An in situ enclosure experiment to test the solar UVB impact on plankton in a high altitude mountain lake. II. Effects on the microbial food web. J Plankton Res 21: 859-876

Tevini M (1993) Molecular biological effects of ultraviolet radiation. In: Tevini $M$ (ed) UV-B radiation and ozone

Editorial responsibility: Frede Thingstad,

Bergen, Norway depletion: effects on humans, animals, plants, microorganisms and materials. Lewis Publishers, Boca Raton, p $1-15$

UNEP (United Nations Environment Program) (1991) Environmental effects of ozone depletion. UNEP, Nairobi

Vernet M (2000) Effects of UV radiation of the physiology and ecology of marine phytoplankton. In: de Mora S, Demers $S$, Vernet $M$ (eds) The effects of UV radiation in the marine environment. Cambridge Environmental Chemistry Series, Vol 10. Cambridge University Press, Cambridge, p 237-278

Villafañe VE, Sundbäck K, Figueroa FL, Helbling EW (2003) Photosynthesis in the aquatic environment as affected by UVR. In: de Mora S, Demers S, Vernet M (eds) The effects of UV radiation in the marine environment. Cambridge Environmental Chemistry Series, Vol 10. Cambridge University Press, Cambridge, p 357-398

Vincent WF, Roy S (1993) Solar ultraviolet-B radiation and aquatic primary production: damage protection and recovery. Environ Rev 1:1-12

Weiler CS, Penhale PA (1994) Preface. In: Weiler CS, Penhale PA (eds) Ultraviolet radiation in Antarctica. Measurements and biological effects. Antarctic Research Series, Vol 62. American Geophysical Union, Washington, DC, p xi-xii

Wickham S, Carstens M (1998) Effects of ultraviolet-B radiation on two Arctic microbial food webs. Aquat Microb Ecol 16:163-171

Submitted: August 12, 2003; Accepted: July 28, 2005

Proofs received from author(s): January 27, 2006 